Volume 3 Issue 1, March 2018: pp. 1-10. Copyright @ LamLaj. Faculty of Law, Lambung Mangkurat University, Banjarmasin, South Kalimantan, Indonesia. ISSN: 2502-3136 | e-ISSN: 2502-3128. Open Access at: http://lamlaj.ulm.ac.id/web/

\title{
PEMBATALAN PUTUSAN ARBITRASE BERDASARKAN UNDANG- UNDANG NOMOR 30 TAHUN 1999 TENTANG ARBITRASE DAN ALTERNATIF PENYELESAIAN SENGKETA
}

\author{
Azzanira $^{1}$, Annalisa $Y^{2}$, dan Muhammad Syaifuddin ${ }^{3}$ \\ ${ }^{1}$ Alumni Magister Ilmu Hukum Universitas Sriwijaya, Advokat PERADI \\ Email:azzanira@yahoo.co.id \\ ${ }^{2}$ Fakultas Hukum Universitas Srwijaya Palembang-Sumatera Selatan. \\ Email: annalisa_yahanan@yahoo.com \\ ${ }^{3}$ Fakultas Hukum Universitas Srwijaya Palembang-Sumatera Selatan. \\ Email:syaifuddin_unsri@yahoo.com
}

Submitted : 14/01/2018 Reviewed 21/03/2018 Accepted:22/03/2018

\begin{abstract}
The award of arbitration shall be final, having a permanent legal force and binding on the parties. Although it is final but can still be submitted a request for cancellation to the District Court and the Supreme Court. In Law Number 30 of 1999 Concerning Arbitration and Alternative Dispute Resolution. Teleological Meaning in Article 60 of Law No 30 Year 1999 states that final, permanent and binding legal arbitration ruling may be accepted by the disputing parties without any request for cancellation at a later date. Meanwhile Article 70 provides an opportunity to apply for a cancellation to the District Court as well as to the Supreme Court. Although an arbitration ruling may be filed with a request for cancellation, this does not remove the binding and permanent legal nature of the arbitral award, but it is not final as it may still be subject to a cancellation request. In conclusion, the arbitration law arrangements that should be in line with the objectives and basic functions of the law are arbitration rulings that create legal certainty, legal justice, and legal benefit, and the purpose of arbitration creates a benefit solution principle will be achieved well. Thus, Law No. 30 of 1999 can be applied, in the hope that there will be no request for cancellation of the arbitral award in the future.
\end{abstract}

Keywords; arbitration; the cancellation of the arbitral award; final; binding

Abstrak: Putusan arbitrase bersifat final, mempunyai kekuatan hukum tetap dan mengikatpara pihak. Meskipun bersifat final tetapi masih dapat diajukan permohonan pembatalan ke Pengadilan Negeri Maupun Mahkamah Agung. Dalam UndangUndang Nomor 30 tahun 1999 Tentang Arbitrase dan Alternatif Penyelesaian Sengketa. Makna teleologis Pasal 60 UU No 30 Tahun 1999 menyebutkan putusan arbitrase yang sifatnya final, berkekuatan hukum tetap dan mengikat dapat diterima 
oleh para pihak yang bersengketa tanpa adanya upaya permohonan pembatalan di kemudian hari. Sementara itu Pasal 70 memberikan kesempatan untuk mengajukan permohonan pembatalan ke Pengadilan Negeri maupun ke Mahkamah Agung. Meskipun putusan arbitrase dapat diajukan permohonan pembatalan, hal ini tidak menghilangkan sifat mengikat dan berkekuatan hukum tetap terhadap putusan arbitrase, tetapi belum final karena masih dapat diajukan permohonan pembatalan. Kesimpulan, pengaturan hukum arbitrase yang seharusnya sesuai dengan tujuan dan fungsi dasar hukum yaitu putusan arbitrase yang menciptakan kepastian hukum, keadilan hukum, dan kemanfaatan hukum, dan tujuan arbitrase menciptakan prinsip benefit solution akan tercapai dengan baik. Sehingga, UU No 30 Tahun 1999 dapat diterapkan, dengan harapan tidak ada permohonan pembatalan putusan arbitrase di masa yang akan datang.

Kata kunci: arbitrase; pembatalan putusan arbitrase; final; mengikat.

\section{PENDAHULUAN}

Penyelesaian sengketa merupakan salah satu dari rangkaian kegiatan transaksi. Penyelesaian sengketa yang dapat diterima oleh pihak yang bersengketa akan mencegah berkembangnya sengketa menjadi disintegrasi dalam kehidupan masyarakat. ${ }^{1}$ Dengan meningkatnya hubungan bisnis maka perlu ada sistem penyelesaian sengketa yang efisien, efektif, dan cepat, sehingga dalam menghadapi liberalisasi perdagangan terdapat lembaga yang dapat diterima dunia bisnis dan memiliki kemampuan sistem untuk menyelesaikan sengketa dengan cepat dan biaya murah.

Bentuk-bentuk Alternatif Penyelesaian Sengketa dapat dibagi dalam : Pertama, alternative to ajudikasi yang terdiri atas negosiasi dan mediasi; Kedua, alternative to litigasi yang terdiri atas negosiasi, mediasi dan arbitrase. $^{2}$

1 Peter Mahmud Marzuki. 1999. Tanggapan Terhadap Rancangan Undang-Undang Penyelesaian Sengketa, Seminar Sehari tentang Alternatif Penyelesaian Sengketa. Jakarta: Departemen Kehakiman dan The Asia Foundantion, hlm.1-2.

2 Abdul Halim Baraktullah. 2010. "Bentuk Perlindungan Hukum Bagi Konsumen Dalam
Penyelesaian sengketa secara litigasi, dalam praktek terdapat alternatif penyelesaian sengketa (alternative dispute resolution), yang disebut dengan arbitrase. ${ }^{3}$ Majemuknya masyarakat Indonesia, serta semakin banyaknya benturan kepentingan dan pendapat, penerapan arbitrase dipercaya dapat memainkan peranan dalam memelihara keseimbangan sosial. ${ }^{4}$ Meningkatnya hubungan bisnis terhadap alasan-alasan tersebut, maka meningkat pula kebutuhan akan arbitrase. ${ }^{5}$

Sebagai tindak lanjut atas perkemban-

Penyelesaian Sengketa Transaksi Elektronik International Menurut UU No.11 Tahun 2008”. Jurnal Hukum Bisnis. 29.(1):57

3 Frans Hendra Winarta. 2011. Hukum Penyelesaian Sengketa Arbitrase Nasional Indonesia \& Internasional. Jakarta: Sinar Grafika, hlm.2

4 Qipra Galang Kualita. 1997. "Pelembagaan Penyelesaian Sengketa Perundingan dan Arbitrase di Indonesia”. Makalah Kebijakan (Policy Paper). Jakarta: kerjasama dengan Yayasan Akatiga, ICEL (Indonesian Center for Environment Law) dan LPPM (Lembaga Pendidikan dan Pengembangan Manajemen). hlm.28

5 Karen Mills. Arbitration Indonesia, www.karims yah.com/i magescontent/ article/20050922160918.pdf, hlm.2. Diakses. 01 Maret 2013, pukul 19:05 WIB. 
gan dunia usaha dan hukum maka pada tanggal 12 Agustus 1999, pemerintah Indonesia mengundangkan Undang-Undang Nomor 30 Tahun 1999 tentang Arbitrase dan Alternatif Penyelesaian Sengketa. Pasal 1 angka 1 Undang-Undang Nomor 30 Tahun 1999 tentang Arbitrase dan Alternatif Penyelesaian Sengketa, menjelaskan pengertian arbitrase yaitu : "Arbitrase adalah cara penyelesaian suatu sengketa perdata di luar peradilan umum yang didasarkan pada perjanjian arbitrase yang dibuat secara tertulis oleh para pihak yang bersengketa".

Arbitrase merupakan salah satu cara penyelesaian sengketa di luar Pengadilan yang banyak diminati para pelaku bisnis dikarenakan adanya kelebihan yang dimiliki arbitrase, yaitu :

a. Dijamin kerahasiaan sengketa para pihak;

b. Dapat dihindari kelambatan yang diakibatkan karena hal prosedural dan administratif;

c. Para pihak dapat memilih arbiter yang menurut keyakinannya, mempunyai pengetahuan, pengalaman serta latar belakang yang cukup mengenai masalah yang disengketakan, jujur dan adil;

d. Para pihak dapat menentukan pilihan hukum untuk menyelesaikan masalahnya serta proses dan tempat penyelenggaraan arbitrase; dan

e. Putusan arbiter merupakan putusan yang mengikat para pihak dan dengan melalui tata cara (prosedur) sederhana saja ataupun langsung dapat dilaksanakan. ${ }^{6}$

Arbitrase pada dasarnya menghindari pengadilan, dalam kaitan ini dibandingkan

6 Lihat Penjelasan Umum Undang-Undang No.30 Tahun 1999 Tentang Arbitrase dan Alternatif Penyelesaian Sengketa. LN No.138 Tahun 1999. TLN No.3872. dengan ajudikasi publik, arbitrase lebih memberikan kebebasan, pilihan, otonomi, kerahasian kepada para pihak yang bersengketa. ${ }^{7}$ Berdasarkan penjelasan mengenai pengertian arbitrase dapat terlihat bahwa dalam penyelesaian perselisihan melalui arbitrase terdapat pihak-pihak yang berselisih sebagai akibat hukum yang terjadi dalam dunia bisnis. Di dalam perselisihan tersebut, mereka sepakat untuk menyelesaikan perselisihan diantara mereka dengan menunjuk satu atau beberapa orang arbiter.

Penyelesaian sengketa melalui forum arbitrase menghasilkan suatu putusan arbitrase yang bersifat final and binding, yaitu merupakan putusan akhir dan mempunyai kekuatan hukum tetap dan mengikat para pihak. ${ }^{8}$ Namun ditemukan Pasal yang kontradiktif dalam UU No 30 Tahun 1999. Seperti yang disebutkan dalam Pasal 60 UU No 30 Tahun 1999 yang menjelaskan ketentuan putusan yang mengikat dari lembaga arbitrase dan tidak ada upaya hukum apapun.

Pasal 60 UU No 30 Tahun 1999 :

"Putusan arbitrase bersifat final dan mempunyai kekuatan hukum tetap dan mengikat para pihak.

Namun setelah diteliti lebih lanjut Pasal 60 UU No 30 Tahun 1999 kontradiktif dengan Pasal 70 UU No 30 Tahun 1999 yang menyatakan :

Terhadap putusan arbitrase para pihak dapat mengajukan permohonan pembatalan apabila putusan tersebut diduga mengandung unsurunsur sebagai berikut :

7 Gary Goodpaster.1995. Tinjauan Terhadap Penyelesaian Sengketa, Seri Dasar-Dasar Hukum Ekonomi 2; Arbitrase di Indonesia, Jakarta : Ghalia Indonesia, hlm.7

8 Lihat Pasal 60, Undang-Undang No.30 Tahun 1999 Tentang Arbitrase dan Alternatif Penyelesaian Sengketa. 
a. surat atau dokumen yang diajukan dalam pemeriksaan, setelah putusan dijatuhkan, diakui palsu atau dinyatakan palsu;

b. setelah putusan diambil ditemukan dokumen yang bersifat menentukan, yang disembunyikan oleh pihak lawan; atau

c. putusan diambil dari hasil tipu muslihat yang dilakukan oleh salah satu pihak dalam pemeriksaan sengketa.

Pasal 70 UU No 30 Tahun 1999 memberikan celah hukum bagi pihak yang merasa kepentingan hukumnya dirugikan, pihak yang kalah dalam forum arbitrase yang merasa kurang puas terhadap keputusan seorang Arbiter dalam menyelesaikan sengketa yang terjadi dapat mengajukan permohonan pembatalan putusan arbitrase.

Sejak berlakunya Undang-Undang Arbitrase dan Alternatif Penyelesaian Sengketa tahun 1999 sampai tahun 2015 ada 81 (delapan puluh satu) kasus pembatalan putusan arbitrase. $^{9}$

Jika di lihat dari begitu banyaknya kasus permohonan pembatalan putusan arbitrase yang alasannya telah memenuhi unsur-unsur yang ada dalam Pasal 70 huruf (a),(b),dan (c) UU No 30 Tahun 1999 dan alasan-alasan lain diluar Pasal 70 sangat menjadi problema besar, karena eksistensi Pasal 60 UU No 30 Tahun 1999 sangat dipertanyakan.

Pasal 60 UU No 30 Tahun 1999 menjelaskan bahwa putusan arbitrase bersifat final dan mempunyai kekuatan hukum tetap dan mengikat para pihak dan dengan demikian tidak dapat diajukan banding, kasasi atau peninjauan kembali, tetapi Pasal 70 UU No 30 Tahun 1999 memperbolehkan permohonan pembatalan putusan arbitrase dengan

9 www.mahkamahagung.go.id/putusan. mahkamahagung/perdata-khusus/arbitrase. Diakses 17 Desember 2015, Pukul 20:12 WIB. memenuhi salah satu unsur yang telah disebutkan pada Pasal 70 UU No 30 Tahun 1999. Tujuan lembaga arbitrase untuk menciptakan proses penyelesaian sengketa secara efektif, rahasia para pihak terjamin, waktu yang efisien, namun akan menjadi sia-sia apabila masih ada upaya hukum yang muncul karena adanya proses permohonan pembatalan yang ditujukan ke Pengadilan Negeri dan Mahkamah Agung untuk diperiksa dan diputus lagi oleh Majelis Hakim Pengadilan Negeri maupun Hakim Mahkamah Agung. ${ }^{10}$ Akibat hukum yang terjadi yaitu eksistensi dan fungsi Pasal 60 dan Pasal 70 UU No 30 Tahun 1999 sangat dipertanyakan.

\section{METODE}

Metode penelitian ini adalah Penelitian Hukum Normatif, Sifat penelitian Deskriptif Analisis. Adapun Tipe Penelitian adalah mengenai Kekaburan Hukum Dalam UU No 30 Tahun 1999 dengan tipe pendekatan perundang-undangan (statut approch). Bahan $\mathrm{Hu}-$ kum yang digunakan Bahan hukum primer, sekunder dan tersier. Pengolahan Bahan Hukum yang telah diperoleh di inventarisir kemudian agar mudah disusun dengan sistem kartu (card system). Pembahsan dan Analisis bahan hukum dilakukan berdasarkan rumusan masalah yang dibahas dan ditarik kesimpulan.

10 Lihat Pasal 72 UU No 30 Tahun 1999 :

(1) Permohonan pembatalan putusan arbitrase harus diajukan kepada Ketua Pengadilan Negeri.

(2) Apabila permohonan sebagaimana dimaksud dalam ayat (1) dikabulkan, Ketua Pengadilan Negeri menentukan lebih lanjut akibat pembatalan seluruhnya atau sebagian putusan arbitrase.

(3) Putusan atas permohonan pembatalan ditetapkan oleh Ketua Pengadilan Negeri dalam waktu paling lama 30 (tiga puluh) hari sejak permohonan sebagaimana dimaksud dalam ayat (1) diterima. 


\section{ANALISIS DAN PEMBAHASAN}

Tujuan, dan makna teleologis putusan arbitrase yang bersifat final, berkekuatan hukum tetap dan mengikat menurut Pasal 60 UU No 30 Tahun 1999, yaitu putusan arbitrase merupakan putusan terakhir, tidak dapat diajukan upaya hukum lagi. Putusan arbitrase tidak dapat ditarik kembali, walaupun ada verzet, banding, ataupun kasasi, dapat dikatakan putusan tersebut telah mempunyai kekuatan hukum tetap sehingga mengikat bagi para pihak. Sehingga mempunyai tujuan untuk memberikan kepastian hukum dan memberikan kepercayaan bagi para pihak yang bersengketa dan memilih forum arbitrase untuk menyelesaikan sengketa diantara mereka. Putusan yang dihasilkan melalui forum arbitrase diputus sesuai dengan ketentuan dan keadilan seperti halnya putusan yang diputus di muka pengadilan pada umumnya. Putusan arbitrase yang diputus oleh beberapa orang arbiter yang ditunjuk oleh para pihak menghasilkan putusan arbitrase yang bersifat mengikat dan akhir serta tidak dapat diajukan upaya hukum apapun. Dengan adanya pasal 60 UU No 30 Tahun 1999, para pihak dapat mempercayakan kepada lembaga arbitrase untuk menyelesaikan sengketa diantara mereka kepada forum arbitrase yang memiliki kekuatan mengikat sama dengan putusan pengadilan. Artinya tujuan arbitrase untuk mendapatkan kepercayaan bagi masyarakat terpenuhi.

\section{Makna Upaya Hukum dalam Penjelasan}

(4) Terhadap putusan Pengadilan Negeri dapat diajukan permohonan banding ke Mahkamah Agung yang memutus dalam tingkat pertama dan terakhir.

(5) Mahkamah Agung mempertimbangkan serta memutuskan permohonan banding sebagaimana dimaksud dalam ayat (4) dalam waktu paling lama 30 (tiga puluh) hari setelah permohonan banding tersebut diterima oleh Mahkamah Agung.

\section{Pasal 60 UU No 30 Tahun 1999}

Penjelasan Pasal 60 UU No 30 Tahun 1999 :

"Putusan arbitrase merupakan putusan final dan dengan demikian tidak dapat diajukan banding, kasasi atau peninjauan kembali.

Banding, kasasi dan peninjauan kembali merupakan jenis upaya hukum yang diatur di dalam hukum acara perdata. Upaya hukum yaitu suatu upaya yang diberikan kepada seseorang untuk sesuatu hal tertentu yang melawan keputusan Hakim. Bahwa keputusan Hakim tersebut tidak luput dari kekeliruan ataupun kekhilafan, maka dari itu demi untuk menegakkan kebenaran dan keadilan setiap keputusan Hakim tersebut perlu dimungkinkan untuk diadakan pemeriksaan ulang, sehingga kekeliruan dan kekhilafan yang terjadi dalam keputusan itu dapat diperbaiki menurut semestinya. Jadi pada setiap keputusan Hakim pada umumnya dapat diberikan upaya hukum, yakni upaya atau alat untuk mencegah atau memperbaiki kekeliruan dalam suatu keputusan tersebut. ${ }^{11}$

Dalam UU No 30 Tahun 1999 tidak diatur secara khusus mengenai upaya hukum, tetapi arbitrase tunduk dan mengikuti prosedur dan ketentuan upaya hukum seperti halnya dalam upaya hukum pada hukum acara perdata. Upaya hukum dalam hukum acara arbitrase adalah upaya hukum banding yang diajukan ke Mahkamah Agung, upaya hukum banding pada arbitrase dikenal dengan upaya hukum kasasi, permohonan kasasi ini diajukan ke Mahkamah Agung.

Arbitrase tidak terikat berbagai formalitas, walaupun tetap dalam batas-batas kewajaran hukum, kejujuran, kebenaran, keadilan (putusan ex aequo et bono) arbitrase mampu

11 M.Nur Rasaid. 2005. Hukum Acara Perdata. Jakarta: Sinar Grafika, hlm.61 
memberikan putusan yang adil dan dapat diterima oleh para pihak. ${ }^{12}$

Berdasarkan teori tujuan dan fungsi hukum, hukum memiliki fungsi deklarasi yuridis, dan juga memiliki fungsi proteksi sosiologis, dalam arti hukum mengayomi negara itu sendiri, baik secara preventif (pencegahan) dan represif (penyelesaian/penindakan), serta antisipatif (penyiapan untuk masa yang akan datang), agar terwujud integrasi sosial yang di dalamnya tercipta dan terpelihara kedamaian dan ketentraman dalam kehidupan bermasyarakat, serta ketertiban dan kesejahteraan dalam kehidupan bernegara, sehingga tercapai kebahagiaan dalam berbagai dimensi dan arti seluas-luasnya dalam kehidupan setiap manusia (individu).

Dengan adanya Pasal 60 UU No 30 Tahun 1999 memberikan putusan arbitrase yang final, berkekuatan hukum tetap dan mengikat, dengan tidak adanya para pihak yang membantah putusan arbitrase untuk mengajukan upaya hukum telah menjawab tujuan hukum sebagai fungsi proteksi sosiologis, dengan hadirnya Pasal 60 UU No 30 Tahun 1999 telah memberikan keyakinan dan kepastian bagi pihak-pihak bersengketa untuk mempercayai dan menerima putusan arbitrase yang telah diputuskan, pencegahannya yaitu bersifat final dengan tidak dapat diajukan upaya hukum apapun.

Untuk pihak-pihak yang akan memilih arbitrase sebagai alternatif penyelesain sengketa diharapkan dapat memahami terlebih dahulu hukum, peraturan dan ketentuan yang ada pada UU No 30 Tahun 1999, sehingga putusan arbitrase dapat diterima dan diterapkan

12 Priyatna Abdurrasyid.2002. "Pengusaha Indonesia", dalam Jurnal Hukum Bisnis. 21. Dalam Eman Suparman, Arbitrase \& Dilema Penegakan Keadilan, hlm.163 dengan baik bagi para pihak, dan tidak ada lagi permohonan pembatalan ataupun penyesalan yang muncul di kemudian hari setelah memilih forum arbitrase.

\section{Sifat Final Putusan Arbitrase}

Final dan Mengikat memiliki keterkaitan makna satu sama lain. Menuut Kamus Besar Bahasa Indonesia, frase "final" berarti tahapan terakhir dari rangkaian pemeriksaan. Sedangkan frase "mengikat" berarti menguatkan. Bertolak dari arti harfiah ini, maka frase "final dan mengikat" memiliki arti yang saling terkait, yang berarti akhir dari suatu proses pemeriksaan, telah memiliki kekuatan mengeratkan atau menyatukan semua kehendak dan tidak dapat dibantah lagi. Kekuatan mengikat yaitu jika kedua pihak telah bersepakat untuk menyerahkan kepada pengadilan untuk menyelesaikan sengketa yang terjadi antara mereka, maka dengan demikian kedua pihak harus tunduk terhadap putusan yang dibuat oleh pengadilan atau hakim. ${ }^{13}$

Final dan mengikat juga dipertegas dengan asas-asas umum dalam putusan arbitrase, yaitu asas final dan mengikat yang jelas diatur dalam Pasal 60 UU No 30 Tahun 1999 yang menyatakan : "Putusan arbitrase bersifat final dan mempunyai kekuatan hukum tetap dan mengikat para pihak". ${ }^{14}$

Meskipun pada UU No 30 Tahun 1999 dinyatakan bahwa putusan arbitrase bersifat final, berkekuatan hukum tetap, dan mengikat tetapi sebenarnya putusan arbitrase tersebut belum final, tetapi sudah berkekuatan hukum tetap karena masih dimungkinkan untuk dia-

13 Eman Suparman. 2012. Arbitrase dan Dilema Penegakkan Keadilan. Jakarta: Tanpa Nama Penerbit, hlm.175.

14 Gunawan Widjaja. 2002. Seri Aspek Hukum dalam Bisnis:Arbitrase VS Pengadilan-Persoalan Kompetensi (Absolut) yang Tidak Pernah Selesai. Jakarta:Kencana, hlm.188 
jukan permohonan pembatalan putusan arbitrase oleh pihak yang kalah dalam persidangan di forum arbitrase.

\section{Putusan Arbitrase Berkekuatan Hukum Tetap}

Dalam UU No 30 Tahun 1999 Tentang Arbitrase dan Alternatif Penyelesaian Sengketa, tidak memberikan penjelasan secara detail pengertian putusan yang berkekuatan hukum tetap, begitu juga dalam Kitab Undang-Undang Hukum Perdata. Tetapi dalam Herzien Inladsch Reglemen (HIR) memberikan penjelasan mengenai kekuatan hukum tetap beradasarkan Pasal 195 HIR yang berbunyi sebagai berikut : Dalam perkara perdata oleh karena pihak yang menang telah memperoleh keputusan hakim yang menghukum pihak lawannya maka ia berhak dengan alat-alat yang diperbolehkan oleh undangundang untuk memaksa pihak lawan guna mematuhi keputusan hakim itu. Hak ini memang sudah selayaknya, sebab kalau tidak ada kemungkinan untuk memaksa orang yang dihukum maka peradilan akan tidak ada gunanya. Dalam hal ini tidak ada jalan lain bagi pihak yang menang daripada menggunakan haknya itu dengan perantaraan hakim untuk melaksanakan putusan tersebut, akan tetapi putusan itu harus benar-benar telah dapat dijalankan, telah memperoleh kekuatan pasti, artinya semua jalan hukum untuk melawan keputusan itu sudah dipergunakan, atau tidak dipergunakan karena lewat waktunya, kecuali kalau putusan itu dinyatakan dapat dijalankan dengan segera, walaupun ada perlawanan, banding atau kasasi. ${ }^{15}$

Sudikno Mertokusumo, menegaskan bahwa suatu putusan yang telah memperoleh kekuatan hukum tetap apabila tidak ada lagi

15 Eman Suparman. Op.cit, hlm.178. upaya hukum biasa yang tersedia, sehingga putusan tidak dapat diubah, kecuali melalui peninjauan kembali. ${ }^{16}$ Pada asasnya hanya putusan hakim yang telah memperoleh kekuatan hukum tetap (inkracht van gewijsde) yang dapat di eksekusi. Selain telah memperoleh kekuatan hukum tetap, putusan yang dapat atau perlu dieksekusi hanya putusan-putusan yang bersifat condemnatoir. ${ }^{17}$

Putusan yang telah mempunyai kekuatan hukum tetap dalam perkara perdata mempunyai 3 (tiga) macam kekuatan, yaitu :

a. Putusan yang memiliki kekuatan mengikat, yaitu putusan hakim yang tidak dapat ditarik kembali, walaupun ada verzet, banding, ataupun kasasi, dapat dikatakan putusan tersebut telah mempunyai kekuatan hukum tetap sehingga mengikat. ${ }^{18}$;

b. Putusan yang memiliki kekuatan pembuktian, yaitu putusan dalam bentuk tertulis, yang merupakan akta otentik bertujuan untuk dapat dipergunakan sebagai alat bukti bagi para pihak, baik untuk mengajukan banding atau kasasi. Dalam hukum pembuktian, putusan diartikan bahwa dengan putusan itu telah diperoleh suatu kepastian tentang suatu peristiwa, karena setiap sarana yang memberi kejelasan atau kepastian sesuatu peristiwa mempunyai kekuatan pembuktian, walaupun putusan tersebut tidak mempunyai kekuatan mengikat terhadap pihak ketiga, tetapi

16 Sudikno Mertokusumo.1998. Hukum Acara Perdata Indonesia. Yogyakarta:Liberty, hlm.182

17 Putusan condemnatoir : adalah putusan yang bersifat menghukum pihak yang kalah untuk memenuhi prestasi. Hak perdata penggugat yang dituntutnya terhadap tergugat, diakui kebenarannya oleh hakim. Amar putusan selalu berbunyi "Menghukum .... dan seterusnya".

18 R. Soeparmono. 2005. Hukum Acara Perdata dan Yurisprudensi. Bandung: Mandar Maju, hlm.148 
mempunyai kekuatan pembuktian terhadap pihak ketiga. ${ }^{19}$;

c. Putusan yang memiliki kekuatan eksekutorial, yaitu putusan untuk menyelesaikan persoalan atau sengketa dan menetapkan hak atau hukumnya, terutama putusan itu harus direalisasikan atau dilaksanakan atau dieksekusi secara paksa. Kekuatan mengikat suatu putusan pengadilan belum cukup dan tidak berarti apabila putusan itu tidak direalisir atau dilaksanakan, karena putusan itu menetapkan dengan tegas hak atau hukumnya untuk kemudian direalisir, maka putusan hakim tersebut mempunyai kekuatan eksekutorial, yaitu kekuatan untuk dilaksanakan apa yang telah ditetapkan dalam putusan itu secara paksa oleh alat negara. $^{20}$

\section{Sifat Mengikat Putusan Arbitrase}

Sifat final dan mengikat putusan arbitrase yang menyatakan bahwa Pasal 60 UU No 30 Tahun 1999 telah menjelaskan putusan arbitrase merupakan putusan final dan dengan demikian tidak dapat diajukan banding, kasasi atau peninjauan kembali. Ketentuan putusan yang mengikat dari lembaga arbitrase menegaskan bahwa tidak ada upaya hukum banding, kasasi, dan peninjauan kembali.

Pasal 60 UU No 30 Tahun 1999 menyebutkan :

"Putusan arbitrase bersifat final dan mempunyai kekuatan hukum tetap dan mengikat para pihak."

Mengikat berarti mempunyai kekuatan hukum tetap. Sebagai manifestasi kehendak para pihak, maka putusan mempunyai kekuatan mengikat kepada para pihak, sehingga yang dapat menggunakan kekuatan mengikat putusan adalah para pihak. Putu-

19 Sudikno Mertokusumo. Op.Cit,hlm.148 san mempunyai karakteristik khusus, karena putusan mempunyai kekuatan mengikat bagi para pihak yang berperkara. Sumber kekuatan mengikat putusan, disebabkan karena adanya penyerahan kehendak para pihak kepada pengadilan untuk menjatuhkan putusan atas perkara yang terjadi. ${ }^{21}$

Berdasarkan teori kesepakatan yang dikemukakan oleh Roscoe Pound, mengatakan suatu kesepakatan mengikat karena memang merupakan keinginan para pihak yang menginginkan kesepakatan itu mengikat. Para pihak sendiri yang pada intinya menyatakan kehendaknya untuk mengikatkan diri. Kata sepakat antara pihak terjadi secara disadari antara yang satu dengan yang lain, dan diantaranya saling mengikatkan diri sehingga subjek hukum yang satu berhak atas prestasi dan begitu juga dengan subjek hukum yang lain berkewajiban untuk melaksanakan prestasinya sesuai dengan kesepakatan yang telah disepakati para pihak.

Dalam teori kesepakatan, kata sepakat, merupakan hal yang paling penting. George W. Paton, menyebut, kehendak yang "senyatanya" bukan kehendak yang "dipernyatakan" sebagaimana disebutnya, "a secret mental reservation should be a bar to enforcement since the test is the real will and not the will as declared". Kehendak tersebut harus diberitahukan pada pihak lain, tidak menjadi soal apakah disampaikan secara lisan maupun tertulis. $^{22}$

Para pihak yang telah sepakat untuk memilih forum arbitrase sebagai tempat untuk menyelesaikan sengketa, memiliki alasan karena arbitrase adalah penyerahan sengketa secara sukarela kepada pihak ketiga yang

$21 \quad$ Ibid, hlm.74

22 www. http://bisdan-sigalingging.blogspot. co.id/2014/10/teori-tentang-perjanjian.html 
netral $^{23}$. Hal ini membuktikan bahwa para pihak tersebut akan tunduk dan mengikuti peraturan-peraturan dan prosedur-prosedur yang ada dalam UU No 30 Tahun 1999 yang berlaku di Indonesia.

Eksistensi Pasal 70 UU No 30 Tahun 1999 yang membolehkan pihak yang tidak puas terhadap putusan arbitrase untuk mengajukan upaya permohonan pembatalan yang menyebutkan :

Terhadap putusan arbitrase para pihak dapat mengajukan permohonan pembatalan apabila putusan tersebut diduga mengandung unsur-unsur sebagai berikut

a. surat atau dokumen yang diajukan dalam pemeriksaan, setelah putusan dijatuhkan, diakui palsu atau dinyatakan palsu;

b. setelah putusan diambil ditemukan dokumen yang bersifat menentukan, yang disembunyikan oleh pihak lawan; atau

c. putusan diambil dari hasil tipu muslihat yang dilakukan oleh salah satu pihak dalam pemeriksaan sengketa.

Selanjutnya, dalam Penjelasan Pasal 70 tersebut, ditentukan bahwa :

"Permohonan pembatalan hanya dapat diajukan terhadap putusan arbitrase yang sudah didaftarkan di pengadilan Alasan-alasan permohonan pembatalan yang disebut dalam pasal ini harus dibuktikan dengan putusan pengadilan. Apabila pengadilan menyatakan bahwa alasan-alasan tersebut terbukti atau tidak terbukti, maka putusan pengadilan ini dapat digunakan sebagai dasar pertimbangan bagi hakim untuk mengabulkan atau menolak permohonan.

Meskipun Pasal 60 UU No 30 Tahun 1999 yang menyatakan bahwa putusan arbi-

23 Meria Utama. 2012. Hukum Ekonomi Internasional. Jakarta:Fikahati Aneska, hlm.58 trase bersifat final dan memempunyai kekuatan hukum tetap dan mengikat para pihak, tetapi pada Pasal 70 UU No 30 Tahun 1999 memberikan celah hukum untuk membolehkan upaya permohonan pembatalan putusan arbitrase ke Pengadilan Negeri dan Mahkamah Agung, permohonan pembatalan putusan arbitrase ini dapat diajukan apabila diduga mengandung unsur-unsur pada Pasal 70 huruf (a), (b), dan (c) UU No 30 Tahun 1999. Putusan yang telah diajukan permohonan pembatalan tersebut sifatnya tetap mengikat dan berkekuatan hukum tetap bagi para pihak tetapi belum final, selama putusan arbitrase tersebut belum diputus dan dieksekusi oleh Pengadilan Negeri Maupun Mahkamah Agung.

Hakim Mahkamah Agung dapat mempertimbangkan apakah permohonan pembatalan putusan arbitrase diterima ataupun ditolak meskipun putusan arbitrase tersebut mengandung beberapa unsur yang ada pada Pasal 70 huruf (a), (b), dan (c) UU No 30 Tahun 1999, selama putusan arbitrase yang diajukan permohonan pembatalan belum diputus dan dieksekusi oleh Pengadilan Negeri Maupun Mahkamah Agung, putusan yang telah diajukan permohonan pembatalan tersebut sifatnya sudah mengikat tetapi tidak final bagi para pihak yang bersengketa. Ada 2 (dua) putusan Mahkamah Agung yang akan di analisis yang membuktikan bahwa putusan arbitrase itu tetap mengikat meskipun belum bersifat final.

Putusan arbitrase yang diajukan permohonan pembatalan tersebut telah mengikat dan berkekuatan hukum tetap sesuai dengan ketentuan Pasal 60 UU No 30 Tahun 1999 tetapi belum final karena masih diajukan oleh pihak yang kalah dengan ketentuan pada Pasal 70 huruf a, b, atau c UU No 30 Tahun 1999. Meskipun pada akhirnya Mahkamah Agung 
menolak permohonan pembatalan untuk seluruhnya ataupun sebagian dengan menguatkan putusan Judex Facti. Keadaan seperti ini membuat suatu putusan arbitrase menjadi kurang dipercaya oleh para pihak yang ingin memilih alternatif penyelesaian sengketa melalui jalur arbitrase karena putusan arbitrase yang dinyatakan telah mengikat tetapi dapat diajukan permohonan pembatalan, proses permohonan pembatalan ke Pengadilan Negeri dan permohonan Banding ke Mahkamah Agung sebagai tingkatan terakhir dalam proses peradilan memerlukan waktu yang cukup lama, sehingga kelebihan beracara di arbitrase dengan cara efisien, aman dan tidak memerlukan waktu yang cukup lama akan menjadi siasia. Sehingga keinginan para pebisnis melalui jalur arbitrase akan semakin berkurang karena ketidakjelasan yang ada pada Pasal 60 dan Pasal 70 UU No 30 Tahun 1999.

\section{PENUTUP}

Untuk pihak-pihak yang akan memilih arbitrase sebagai alternatif penyelesain sengketa diharapkan dapat memahami terlebih dahulu hukum, peraturan dan ketentuan yang ada pada UU No 30 Tahun 1999, sehingga putusan arbitrase dapat diterima dan diterapkan dengan baik bagi para pihak, dan tidak ada lagi permohonan pembatalan ataupun penyesalan yang muncul di kemudian hari setelah memilih forum arbitrase.

Makna teleologis putusan arbitrase yang bersifat final, berkekuatan hukum tetap dan mengikat menurut Pasal 60 UU No 30 Tahun 1999, yaitu putusan arbitrase merupakan putusan terakhir, tidak dapat diajukan upaya hukum lagi. Putusan arbitrase tidak dapat ditarik kembali, walaupun ada verzet, banding, ataupun kasasi, dapat dikatakan putusan tersebut telah mempunyai kekuatan hukum tetap sehingga mengikat bagi para pihak. Putusan arbitrase mempunyai tujuan untuk memberikan kepastian hukum dan memberikan kepercayaan bagi para pihak yang bersengketa memilih forum arbitrase untuk menyelesaikan sengketa diantara mereka. Dengan tujuan putusan arbitrase dapat diterima oleh para pihak yang bersengketa tanpa adanya upaya permohonan pembatalan di kemudian hari

Jika terjadi upaya hukum dapat dikatakan putusan arbitrase itu dimohonkan untuk diajukan pembatalan. Pasal 70 UU No 30 Tahun 1999 tidak dapat menghilangkan sifat mengikat dan berkekuatan hukum tetap yang diatur pada Pasal 60 UU No 30 Tahun 1999. Tetapi putusan tersebut belum final karena masih ada peluang untuk mengajukan upaya permohonan pembatalan putusan arbitrase ke Pengadilan Negeri dan Mahkamah Agung, seperti yang ditegaskan pada Pasal 70 huruf (a), (b), atau (c) UU No 30 Tahun 1999 yang menyatakan : surat atau dokumen dinyatakan palsu, atau diakui palsu; ditemukan dokumen yang bersifat menentukan, yang disembunyikan oleh pihak lawan; atau putusan diambil dari hasil tipu muslihat yang dilakukan oleh salah satu pihak dalam pemeriksaan sengketa.

\section{BIBLIOGRAFI}

Abdul, Halim Baraktullah. 2010. "Bentuk Perlindungan Hukum Bagi Konsumen Dalam Penyelesaian Sengketa Transaksi Elektronik International Menurut UU No.11 Tahun 2008". Jurnal Hukum Bisnis.

Goodpaster, Gary. 1995. Tinjauan Terhadap

Penyelesaian Sengketa, Seri Dasar-

Dasar Hukum Ekonomi 2 : Arbitrase di

Indonesia. Jakarta : Ghalia Indonesia. Kualita,Qipra Galang. 1997. Pelembagaan Penyelesaian Sengketa Perundingan dan 
Arbitrase di Indonesia. dalam Makalah Kebijakan (Policy Paper), kerjasama dengan Yayasan Akatiga, ICEL (Indonesian Center for Environment Law) dan LPPM (Lembaga Pendidikan dan Pengembangan Manajemen), Jakarta.

Marzuki, Peter Mahmud. 1999. Tanggapan Terhadap Rancangan Undang-Undang Penyelesaian Sengketa, Seminar Sehari tentang Alternatif Penyelesaian Sengketa, Jakarta:Departemen Kehakiman dengan The Asia Foundantion.

Mertokusumo, Sudikno. 1998. Hukum Acara Perdata Indonesia, Liberty, Yogyakarta.

Mills, Karen.2005. Arbitration Indonesia, www.karimsyah.com/imagescontent/article/20050922160918.pdf, hlm.2. Diakses. 01 Maret 2013.

Priyatna Abdurrasyid. 2002. " Pengusaha Indonesia".Jurnal Hukum Bisnis. Dalam Eman Suparman, Arbitrase \& Dilema Penegakan Keadilan.

Rasaid, M.Nur. 2005. Hukum Acara Perdata. Jakarta: Sinar Grafika.

Soeparmono, R. 2005. Hukum Acara Perdata dan Yurisprudensi, Bandung, Mandar Maju.

Suparman, Eman. 2012. Arbitrase dan Dilema Penegakkan Keadilan. Jakarta.

Utama,Meria. 2012. Hukum Ekonomi Internasional, Jakarta : Fikahati Aneska.

Widjaja, Gunawan. 2002. Seri Aspek Hukum dalam Bisnis :Arbitrase VS PengadilanPersoalan Kompetensi (Absolut) yang Tidak Pernah Selesai, Jakarta : Kencana.

Winarta, Frans Hendra. 2011. Hukum Penyelesaian Sengketa Arbitrase Nasional Indonesia \& Internasional. Jakarta : Sinar Grafika.

www.mahkamahagung.go.id/putusan.mahkamahagung/perdata-khusus/arbitrase.
(Diakses 17 Desember 2015).

www.http://bisdan-sigalingging. blogspot. co.id/2014/10/teori-tentang-perjanjian. html 